\title{
Effects of inventory grids on estimation of tree species diversity in semi-arid forests of Iran
}

\author{
Mehrdad Mirzaei*, Amir Eslam Bonyad, Ismaeil Moradi Emamgheysi, Iraj Hassanzad Navroodi
}

\author{
Department of Forestry, Faculty of Natural Resources, University of Guilan, Sowmeh Sara, Iran
}

\begin{abstract}
Mirzaei, M., Bonyad, A.E., Moradi Emamgheysi, I., Hassanzad Navroodi, I., 2019. Effects of inventory grids on estimation of tree species diversity in semi-arid forests of Iran. Folia Oecologica, 46: 24-29.

Species diversity is one of the most important indices used to evaluate the sustainability of forest communities. The sampling method and the number of plots are factors affecting the estimation of plant biodiversity. In the present study, effects of different inventory grids on estimation of tree species diversity were compared in semi-arid forests of Iran. There were selected 50 hectares of these forests representing the regional forests. Sampling procedures were carried out on circular plots $\left(1,000 \mathrm{~m}^{2}\right)$ within inventory grids, with dimensions of $50 \times 50 \mathrm{~m}$ (200 plots), $100 \times 50 \mathrm{~m}$ (100 plots), $100 \times 100 \mathrm{~m}$ (50 plots), $200 \times 50 \mathrm{~m}(50$ plots $), 200 \times 100$ $\mathrm{m}$ ( 25 plots), and $250 \times 200 \mathrm{~m}$ (10 plots). For each plot, the type of the species and the number of trees were recorded. Simpson (1-D), Hill $\left(\mathrm{N}_{2}\right)$, Shannon-Wiener $\left(\mathrm{H}^{\prime}\right)$, Mc Arthur $\left(\mathrm{N}_{1}\right)$, Smith-Wilson $\left(\mathrm{E}_{\mathrm{var}}\right)$ and Margalef $\left(\mathrm{R}_{1}\right)$ indices were used to estimate the tree species diversity. The inventory grid was evaluated based on the precision and cost criteria $\left(\mathrm{E} \%{ }^{2} \times \mathrm{T}\right)$. The obtained sampling error values showed that the inventory grid consisting of 200 plots exhibited more accuracy for estimating the biodiversity indices. But based on the results of $\mathrm{E} \%{ }^{2} \times \mathrm{T}$, the inventory grid with 25 plots was selected as the most appropriate one for estimating the tree species diversity in semi-arid forests. The results of this study can also serve to estimate the tree species diversity in other semi-arid forests of Iran.
\end{abstract}

\section{Keywords}

biodiversity indices, precision and cost, sampling method, Zagros forests

\section{Introduction}

The terms species diversity and biodiversity are widely used in ecology and in natural resource management. The biological diversity (biodiversity) is a concept involved in the modern scientific and political terminology and in daily life with various social and economic dimensions (ESHAGHI RAD et al., 2017). Increasing and maintaining the biodiversity on Earth is a very important conservation objective (HUNTER, 1999). In addition, the biodiversity of vegetation is our biggest and the least valued asset. To save the biodiversity it is a useful intention (Kováčová and BENčAt', 2013). The monitoring of tree diversity and forest structure is a fundamental pre-requisite for understanding and managing forest ecosystems (Motz et al., 2010). The assessment of forest biodiversity has become an important issue for studying ecosystems and for proposing adequate measures for their conservation (AUBERT et al., 2004). Using the diversity indices is a necessary tool to calculate and quantify the ecosystem diversity status (VAN STRIEN

\footnotetext{
*Corresponding author:
} 
et al., 2012; BANDEIRA et al., 2013). Tree diversity indices are also good quantitative descriptors for forest structures (Aguirre et al., 2003; Lexerod and Eid, 2006; PommeRENING, 2002; STERBA and ZINGG, 2006), which is a key pre-requisite for understanding the interactions between the patterns and processes in forest ecosystems. Calculation and comparison of different diversity indices has been recognized as a favorite method for studying biodiversity. These indices estimate biological and ecological quality of ecosystems through the structure of their communities (DANILOv and EKelund, 1999); they are also possible indicators for monitoring the level of environmental pollution (WASHINGTON, 1984). In addition to diversity indices, the most important factors for investigation of biodiversity are: sampling plot size, plot shape, number of plots and inventory grid. Varying number of plots affected the results of studies. In the past, the studies were performed with different plot sizes, plot numbers and inventory grids. For example, WANG et al. (2008) studying diversity in the Changbai Nature Reserve (located along the border of China and North Korea) used $10 \times 10 \mathrm{~m}$ quadrats at five different locations. AliJANPOUR et al. (2009) investigated 92 transects, each $30 \mathrm{~m}$ long, located in an inventory grid of $150 \mathrm{~m} \times 300 \mathrm{~m}$, to compare the woody plants diversity in Arasbaran forests of Iran. EвRAнImI et al. (2014) used 25 circular plots $\left(1,000 \mathrm{~m}^{2}\right)$ with $100 \mathrm{~m} \times 200 \mathrm{~m}$ grid spacing for investigation of the biodiversity in northern forests of Iran. EтемAD et al. (2014) used quadrat plots sized 100 $\mathrm{m}^{2}, 225 \mathrm{~m}^{2}, 400 \mathrm{~m}^{2}$ and $1,600 \mathrm{~m}^{2}$ for studying the tree species diversity in Zagros forests of Iran; and these authors showed that the quadrat plots $1,600 \mathrm{~m}^{2}$ and $400 \mathrm{~m}^{2}$ were the most appropriate sizes for determining the tree species diversity. In the study of Pourbabaei and Rahimi (2016), there were used 20 circular plots $\left(1,000 \mathrm{~m}^{2}\right)$ established based on selective sampling method for investigating the effects of conservation on plant species diversity in western forests of Iran. We can see that various studies have been carried out on the plot size, but there has been accomplished no study dealing with the effect of number of sampling plots on the biodiversity estimation. So, the aim of the present study was to compare different inventory grids (numbers of plots): $50 \times 50 \mathrm{~m}$ (200 plots), $100 \times 50$ $\mathrm{m}$ (100 plots), $100 \times 100 \mathrm{~m}(50$ plots $), 200 \times 50 \mathrm{~m}(50$ plots), $200 \times 100 \mathrm{~m}$ ( 25 plots $)$, and $250 \times 200 \mathrm{~m}$ (10 plots $)$ in order to estimate the tree species diversity in semi-arid forests of Iran.

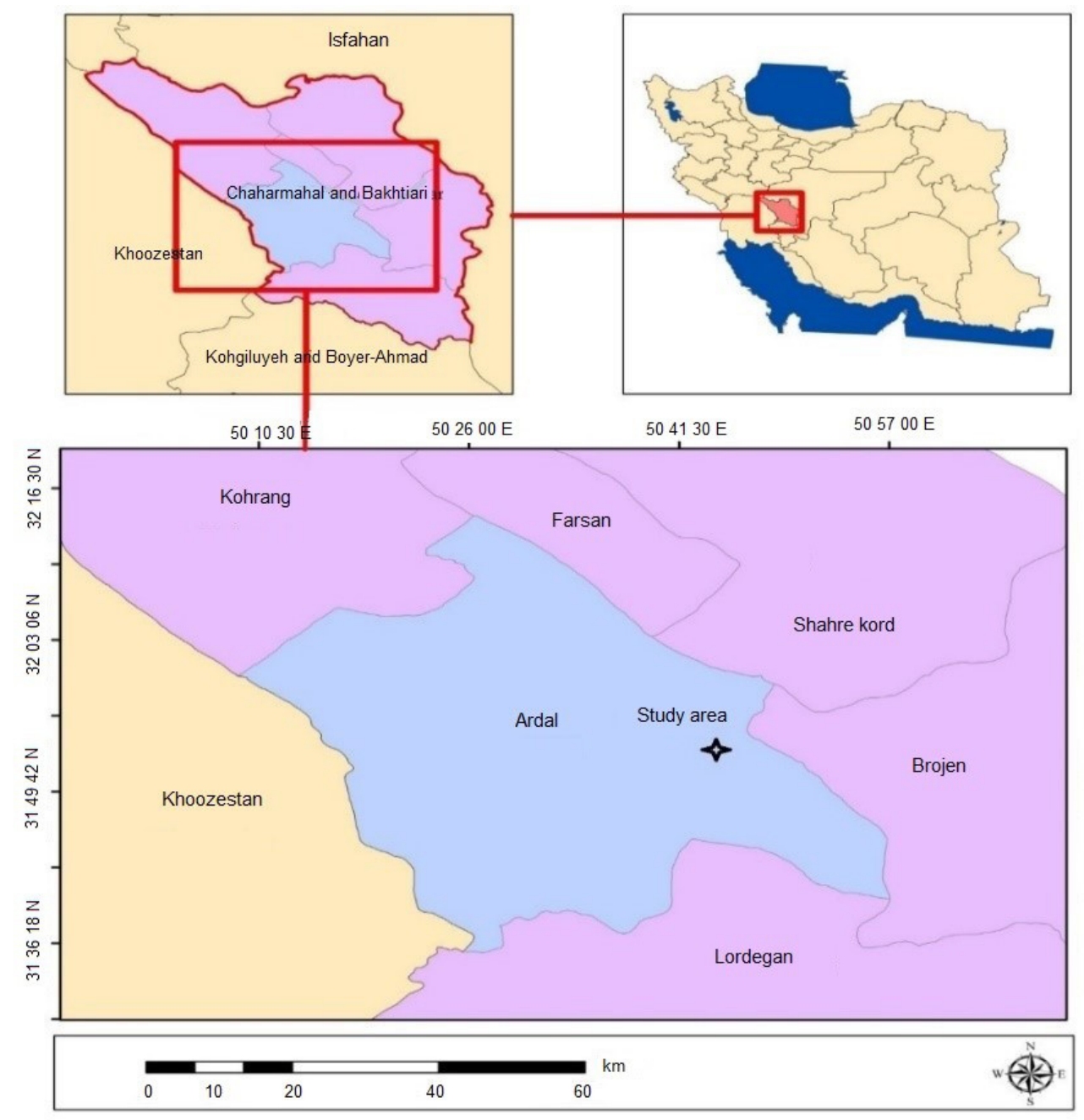

Fig. 1. Location of study area. 


\section{Materials and methods}

\section{Study area}

This study was carried out in Zagros forests of Iran known as Ardal protected forests. The studied locality had a total area of 50 hectares, and it was located between $50^{\circ} 48^{\prime} 39^{\prime \prime} \mathrm{E}$ and 50 50' $11^{\prime \prime} \mathrm{E}$ longitude and $31^{\circ} 50^{\prime} 34^{\prime \prime}$ and $31^{\circ} 52^{\prime} 44^{\prime \prime} \mathrm{N}$ latitude (Fig. 1), with elevation ranging between 2,100 to $3,100 \mathrm{~m}$ above mean sea level, the average annual rainfall $530.15 \mathrm{~mm}$ and the average annual temperature $15.4{ }^{\circ} \mathrm{C}$. This area has a semi-humid climate according to the DeMartonne climate classification. In the present study, the data were collected following the systematic random sampling method with different inventory grids. These inventory grids are shown in Table 1.

Table 1. Number of plots with different inventory grid

\begin{tabular}{ccc}
\hline Row & Number of plots & Inventory grid $(\mathrm{m})$ \\
\hline 1 & 200 & $50 \times 50$ \\
2 & 100 & $100 \times 50$ \\
3 & 50 & $100 \times 100$ \\
4 & 50 & $200 \times 50$ \\
5 & 25 & $200 \times 100$ \\
6 & 10 & $250 \times 200$ \\
\hline
\end{tabular}

Then, different number of plots (circular plots with $1,000 \mathrm{~m}^{2}$ ) were selected, and on each plot there were measured and recorded the following variables: type of species, number of species, number of trees and diameter at breast height (DBH).

For studying the tree species diversity, six commonly used biodiversity indices were selected, see Table
2 (Krebs, 1999; SCOtT and Anderson, 2003; MAgUrRan, 2004, EsHAGHI RAD et al., 2017). The biodiversity indices were compared based on a full calipering inventory $(100 \%$ survey). In other words, the actual values of biodiversity indices were calculated using full calipering inventory data and then these indices were used as criteria for comparison of the results.

\section{Comparing among different inventory grids based on $\mathbf{E} \%^{2} \times \mathbf{T}$}

The cost and precision are two factors important in forest studies. It is difficult to measure the cost of an inventory, but with regard to the direct relationship existing between the inventory financial costs and the required time, the present study has been focused on the inventory time. According to Eq. 1, the total time for each inventory grid is (HEIDARI et al., 2009)

$$
T=\left(n \times t_{i}\right)+\left(n \times t_{j}\right),
$$

where $\mathrm{T}$ is the total time needed for each inventory grid, $n$ is the number of plots in the grid, $t_{i}$ is the average time of trees measured on each plot, and $t_{j}$ is the average time needed to overcome the distance between the plots.

The percentage of inventory error $(\mathrm{E} \%)$ is calculated according to Eq. 2 and 3.

$$
\begin{aligned}
& \mathrm{E}=\mathrm{t} \times \mathrm{S}_{\bar{x}} \\
& \mathrm{E} \%=\frac{\mathrm{E} \times 100}{\overline{\mathrm{x}}},
\end{aligned}
$$

where $\mathrm{E}$ is the inventory error (precision), $\mathrm{t}$ is the statistic of t-student table, $\mathrm{S}_{\bar{x}}$ is the standard error and $\overline{\mathrm{x}}$ is the

\begin{tabular}{|c|c|}
\hline Index & Equation \\
\hline Simpson (1-D) & $1-D=1-\sum_{i=1}^{S}\left[\frac{n_{i}\left(n_{i}-1\right)}{N(N-1)}\right]$ \\
\hline Shannon-Wiener $\left(\mathrm{H}^{\prime}\right)$ & $H^{\prime}=-\sum_{i=1}\left(P_{i}\right)\left(\log _{2} P_{i}\right)$ \\
\hline Hill $\left(\mathrm{N}_{2}\right)$ & $\frac{1}{D}=\frac{1}{\sum p_{i}^{2}}$ \\
\hline $\operatorname{Mc} \operatorname{Arthur}\left(\mathrm{N}_{1}\right)$ & $N_{1}=e^{H^{\prime}}$ \\
\hline Smith-Wilson's evenness ( $\left.E_{\text {var }}\right)$ & $E_{v a r}=1-\left(\frac{2}{\pi}\right)\left[\arctan \left\{\frac{\sum\left(\log _{e}\left(n_{i}\right)-\sum \log _{e}\left(n_{j}\right) / s\right)^{2}}{s}\right\}\right.$ \\
\hline Margalef's richness $\left(\mathrm{R}_{1}\right)$ & $R_{1}=\frac{S-1}{\operatorname{Ln}(N)}$ \\
\hline
\end{tabular}
mean diversity index.

Table 2. Biodiversity indices and its equations 
Table 3. Mean of diversity indices in different grid dimension

\begin{tabular}{ccccccc}
\hline \multirow{2}{*}{ Inventory grid $(\mathrm{m})$} & \multicolumn{9}{c}{ Diversity indices } \\
\cline { 2 - 7 } & $1-\mathrm{D}$ & $\mathrm{H}^{\prime}$ & $\mathrm{N}_{2}$ & $\mathrm{~N}_{1}$ & $\mathrm{E}_{\text {var }}$ & $\mathrm{R}_{1}$ \\
\hline $50 \times 50$ & 0.361 & 0.704 & 1.305 & 1.424 & 0.540 & 0.494 \\
$100 \times 50$ & 0.404 & 0.792 & 1.461 & 1.587 & 0.598 & 0.537 \\
$100 \times 100$ & 0.382 & 0.750 & 1.364 & 1.501 & 0.531 & 0.553 \\
$200 \times 50$ & 0.382 & 0.738 & 1.376 & 1.494 & 0.561 & 0.506 \\
$200 \times 100$ & 0.493 & 0.941 & 1.745 & 1.906 & 0.718 & 0.701 \\
$250 \times 200$ & 0.377 & 0.778 & 1.466 & 1.653 & 0.584 & 0.589 \\
\hline
\end{tabular}

Table 4. Inventory Error (E\%) of diversity indices for different grid dimension

\begin{tabular}{crrrrrr}
\hline \multirow{2}{*}{ Inventory grid $(\mathrm{m})$} & \multicolumn{7}{c}{ Diversity indices } \\
\cline { 2 - 7 } & \multicolumn{1}{c}{$1-\mathrm{D}$} & \multicolumn{1}{c}{$\mathrm{H}^{\prime}$} & \multicolumn{1}{c}{$\mathrm{N}_{2}$} & \multicolumn{1}{c}{$\mathrm{N}_{1}$} & \multicolumn{1}{c}{$\mathrm{E}_{\text {var }}$} & $\mathrm{R}_{1}$ \\
\hline $50 \times 50$ & 8.669 & 9.140 & 8.845 & 8.802 & 8.545 & 9.683 \\
$100 \times 50$ & 11.072 & 11.519 & 10.902 & 10.977 & 10.820 & 12.351 \\
$100 \times 100$ & 18.434 & 19.432 & 18.680 & 18.767 & 18.295 & 20.913 \\
$200 \times 50$ & 16.208 & 17.026 & 15.956 & 16.043 & 16.134 & 17.222 \\
$200 \times 100$ & 15.920 & 17.606 & 15.850 & 16.213 & 14.733 & 19.487 \\
$250 \times 200$ & 39.819 & 43.087 & 36.952 & 38.038 & 33.160 & 47.352 \\
\hline
\end{tabular}

Table 5. Comparison of mean diversity indices in sampling methods based on ANOVA test

\begin{tabular}{|c|c|c|c|c|c|c|}
\hline Index & Source & Sum of Squares & $\mathrm{df}$ & Mean Square & $\mathrm{F}$ & Sig. \\
\hline \multirow{3}{*}{$1-\mathrm{D}$} & Between Groups & 0.444 & 5 & 0.089 & 1.172 & $0.322^{\mathrm{ns}}$ \\
\hline & Within Groups & 32.486 & 429 & 0.076 & & \\
\hline & Total & 32.930 & 434 & & & \\
\hline \multirow{3}{*}{$\mathrm{H}^{\prime}$} & Between Groups & 1.531 & 5 & 0.306 & 0.979 & $0.430^{\mathrm{ns}}$ \\
\hline & Within Groups & 134.124 & 429 & 0.313 & & \\
\hline & Total & 135.655 & 434 & & & \\
\hline \multirow{3}{*}{$\mathrm{N}_{2}$} & Between Groups & 5.187 & 5 & 1.037 & 1.082 & $0.370^{\mathrm{ns}}$ \\
\hline & Within Groups & 411.504 & 429 & 0.959 & & \\
\hline & Total & 416.692 & 434 & & & \\
\hline \multirow{3}{*}{$\mathrm{N}_{1}$} & Between Groups & 6.217 & 5 & 1.243 & 1.076 & $0.373^{\mathrm{ns}}$ \\
\hline & Within Groups & 495.740 & 429 & 1.156 & & \\
\hline & Total & 501.956 & 434 & & & \\
\hline \multirow{3}{*}{$E_{\text {var }}$} & Between Groups & 0.880 & 5 & 0.176 & 1.136 & $0.341^{\mathrm{ns}}$ \\
\hline & Within Groups & 66.459 & 429 & 0.155 & & \\
\hline & Total & 67.339 & 434 & & & \\
\hline \multirow{3}{*}{$\mathrm{R}_{1}$} & Between Groups & 1.080 & 5 & 0.216 & 1.220 & $0.299^{\mathrm{ns}}$ \\
\hline & Within Groups & 75.945 & 429 & 0.177 & & \\
\hline & Total & 77.025 & 434 & & & \\
\hline
\end{tabular}

ns, not significant different at the 0.05 probability level.

Table 6 . Values of $\mathrm{E} \%{ }^{2} \times \mathrm{T}$ criteria for different grid dimension

\begin{tabular}{ccccccc}
\hline \multirow{2}{*}{ Inventory grid $(\mathrm{m})$} & \multicolumn{5}{c}{ Diversity indices } \\
\cline { 2 - 7 } & $1-\mathrm{D}$ & $\mathrm{H}^{\prime}$ & $\mathrm{N}_{2}$ & $\mathrm{~N}_{1}$ & $\mathrm{E}_{\text {var }}$ & $\mathrm{R}_{1}$ \\
\hline $50 \times 50$ & $6,262.151$ & $6,962.010$ & $6,519.466$ & $6,456.246$ & $6,083.992$ & $7,812.746$ \\
$100 \times 50$ & $5,107.442$ & $5,527.526$ & $4,951.103$ & $5,020.216$ & $4,877.015$ & $6,354.603$ \\
$100 \times 100$ & $7,078.567$ & $7,865.426$ & $7,268.283$ & $7,336.634$ & $6,971.776$ & $9,110.291$ \\
$200 \times 50$ & $5,471.725$ & $6,038.349$ & $5,303.423$ & $5,361.191$ & $5,421.917$ & $6,178.423$ \\
$200 \times 100$ & $2,638.351$ & $3,226.664$ & $2,615.215$ & $2,736.361$ & $2,259.655$ & $3,952.962$ \\
$250 \times 200$ & $6,595.868$ & $7,723.141$ & $5,680.227$ & $6,018.981$ & $4,574.157$ & $9,327.780$ \\
\hline
\end{tabular}


The formula $\mathrm{E} \%{ }^{2} \times \mathrm{T}$, estimating the sampling methods, was used to identify the most economical and smart survey method for estimating the tree species diversity (LoETSCH et al., 1973; Husch et al., 1982). Thus, the inventory grid with the lowest $\mathrm{E} \%{ }^{2} \times \mathrm{T}$ was found as the most appropriate one. The data were analyzed with an IBM SPSS Statistic 22, Ecological Methodology version 6, PAST version 1.89 software.

\section{Results}

The mean of indices diversity calculated for different inventory grids are in Table 3 . The inventory grid of $50 \times 50$ $\mathrm{m}$ and $200 \times 100 \mathrm{~m}$ have the lowest and the highest mean diversity indices, respectively. Besides, the inventory error or the precision of sampling method showed that the inventory grid of $50 \times 50 \mathrm{~m}$ provided more accuracy than the other inventory grids. The results of the inventory error are in Table 4.

In addition to the ANOVA test performed with the aim to determine the appropriate inventory grid used $\mathrm{E} \%{ }^{2} \times \mathrm{T}$ criteria. The results of this estimating parameter showed that the inventory grid of $200 \times 100 \mathrm{~m}$ ( 25 plots $)$ had the lowest value of $\mathrm{E} \%{ }^{2} \times \mathrm{T}$ and, as such, it has been selected as the most appropriate grid dimension. The results of $\mathrm{E} \%{ }^{2} \times \mathrm{T}$ criterion are shown in Table 6 . An ANOVA test showed that there was no significant difference between the different inventory grids as for estimation the diversity indices. The results of ANOVA test are shown in Table 5.

\section{Discussion}

Generally, biodiversity measurements typically focus on the species level, and the species diversity is one of the most important indices used for the evaluation of ecosystems at different scales. The former studies were carried out on different inventory grids (numbers of plots) - in order to estimate the biodiversity indices, there, however have not been concluded either an appropriate number of plots or appropriate grid dimension. In the present study, different inventory grids (or numbers of plots) were tested for estimation of the biodiversity indices in semi-arid forest of Iran, and the results showed that the inventory grid with a spacing of $50 \times 50 \mathrm{~m}$ displayed the lowest sampling error in context of estimation of the biodiversity indices (Table 4). This seems self-explanatory, as in this case, the number of plots is higher than in the other inventory grids. The inventory grid of $50 \times 50 \mathrm{~m}$ also displayed the means of biodiversity indices lower compared to the other inventory grids (Table 3 ). This means that the mean values of biodiversity indices for this inventory grid were close to the actual means of the biodiversity indices - because in this inventory grid, more plots were investigated. The results also showed that the sampling error of the inventory grid of $250 \times 200 \mathrm{~m}$ was higher compared to the other inventory grids. The ANOVA test showed that there was no significant difference between the different inventory grids, and to determine an appropriate inventory grid, an estimator of $\mathrm{E} \%{ }^{2} \times \mathrm{T}$ was applied. Besides the precision, the inventory costs are important, with a crucial role in the selection of the sampling method for forest inventory. Thus, the results of $\mathrm{E} \% \%^{2} \times \mathrm{T}$ criteria showed that the inventory grid of $200 \times 100 \mathrm{~m}$ ( 25 plots $)$ had the lowest value of $\mathrm{E} \%^{2} \times \mathrm{T}$ and, consequently, this grid dimension is the most appropriate for the estimation of biodiversity indices in semi-arid forests of Iran (Table 6). The results also showed that the grid dimension of $100 \times 100 \mathrm{~m}$ (50 plots) had a higher value of $\mathrm{E} \%{ }^{2} \times \mathrm{T}$. Various studies have been carried out on the use of $\mathrm{E} \%{ }^{2} \times \mathrm{T}$ criteria in order to select the most suitable sampling method (MIRZAEI and BONYAD, 2014; MirzaEI et al., 2015) or the most appropriate plot size (ETEMAD et al., 2014). The proper selection of inventory grid and number of plots with the purpose to estimate the forest variables can to a considerable extent prevent the current and future costs and provide the forest managers with accurate information about the forest condition in as short time as possible, to ensure as much as possible effectiveness in the management and planning of forest units.

\section{Conclusion}

The knowledge of effects of implementing forest management systems on regeneration density and species diversity is very important and essential for forest conservation and sustainable development. The plant diversity plays crucial ecological roles in forest ecosystems, by influencing succession, resilience and nutrient cycling in these ecosystems. Therefore, this study was carried out in semi-arid forests of Iran to optimize the required number of plots for estimation of the tree species diversity. The diversity data will be used as a register material and data base for future management and long-term ecological studies. Based on the results of this study, the inventory grid of $200 \times 100 \mathrm{~m}$ ( 25 plots) was recognised as a time and cost effective grid which can be used for describing the tree species diversity in forests of similar type.

\section{References}

Aguirre, O., Hui, G.Y., Von Gadow, K., JimÉnez, J., 2003. An analysis of spatial forest structure using neighborhood-based variables. Forest Ecology and Management, 183: 137-145.

Alijanpour, A., Eshaghi Rad, J., Banej Shafiei, A., 2009. Comparison of woody plants diversity in protected and non-protected areas of Arasbaran forests. Iranian Journal of Forest and Poplar Research, 17 (1): 125-133.

Aubert, M., Alard, D., Bureau, F., 2004. Effect of tree mixture on the humic epipedon and vegetation diversity in managed beech forests (Normandy, France). Forest Ecology and Management, 175: 321-337.

Bandeira, B., Jamet, J.L., Jamet, D., Ginoux, J.M., 2013. Mathematical convergences of biodiversity indices. Eco- 
logical Indicators, 29: 522-528.

Danilov, R., Ekelund, N.G.A., 1999. The efficiency of seven diversity and one similarity indices based on phytoplankton data for assessing the level of eutrophication in lakes in central Sweden. Science of the Total Environment, 234: 15-23.

Ebrahimi, S., Pourbabaei, H., Potheir, D., Omidi, A., TorkAMAN, J., 2014. Effect of livestock grazing and human uses on herbaceous species diversity in oriental beech (Fagus orientalis Lipsky) forests, Guilan, Masal, northern Iran. Journal of Forestry Research, 25 (2): 455-462.

Eshaghi RaD, J., Valadi, G., Zargaran, M.R., 2017. Effects of man-made disturbances on understory plant richness of oak forests in Iran. Folia Oecologica, 44: 61-68.

Etemad, S., Zobeiry, M., Namiranian, M., Ghahramany, L., 2014. Determine the most appropriate surface sampling method for estimating spiral tree diversity in the forests of northern Zagros. In Proceedings of the Second National Conference on Science Student Forests. Tehran University, Karaj, 7-8 May 2014. 6 p.

Heidari, R.H., Zobeiri, M., Namiranian, M., Sobhani, H., 2009. Comparison of circular plot and transect sampling methods in the Zagros Oak Forest (Case study: Educational and research forest of Razi University, Kermanshah province). Iranian Journal of Forest and Poplar Research, 17 (3): 359-368.

HunTER, L.M., 1999. Maintaining biodiversity in forest ecosystems. Cambridge: Cambridge University Press. 698 p.

Husch, B., Miller, C.I., BeERS, T.W., 1982. Forest mensuration. New York: Roland Press Company. 402 p.

Kováčoví, I., BenČaŤ, T., 2013. Evaluation of woody species in the selected parts of south-western Slovakia. Folia Oecologica, 40: 55-64.

Krebs, C.J., 1999. Ecological methodology. 2nd ed. Reading: Benjamin Cummings. 620 p.

LEXEROD, N., EID, T., 2006. An evaluation of different diameter diversity indices based on criteria related to forest management planning. Forest Ecology and Management, 222: $17-28$.

Loetsch. F., Zohrer. F., Haller. K.E., 1973. Forest inven- tory. Munchen: BLV Verlagsgesellschaft. 905 p.

MagurRan, A.M., 2004. Measuring biological diversity. Oxford: Blackwell Science Ltd. 256 p.

Mirzaei, M., Bonyad, A.E., 2014. Defining the most appropriate transect method for estimation of Basal area: case study in Dalab forests, Ilam Province. Iranian Journal of Forest and Poplar Research, 22 (1): 90-98.

Mirzaei, M., Bonyad, A.E., Mohebi Bijarpas, M., GolmoHAMADI, F., 2015. Easy and quick survey method to estimate quantitative characteristics in the thin forests. Journal of Forest and Environmental Science, 31 (2): 73-77.

Motz, K., Sterba, H., Pommerening, A., 2010. Sampling measures of tree diversity. Forest Ecology and Management, 260: 1985-1996.

Pommerening, A., 2002. Approaches to quantifying forest structures. Forestry, 75: 305- 324.

Pourbabaei, H., Rahimi, V., 2016. Effect of conservation on plant species diversity, Kurdistan, western Iran. Journal of Forest and Environmental Science, 32 (1): 10-19.

Scott, W.A., ANDERson, R., 2003. Temporal and spatial variation in carabid assemblages from the United Kingdom environmental change network. Biological Conservation, 110: $197-210$

Sterba, H., ZingG, A., 2006. Distance dependent and distance independent description of stand structure. Allgemeine Forst- und Jagdzeitung, 8 (9): 169-176.

Van Strien, A.J., SoldaAt, L.L., Gregory, R.D., 2012. Desirable mathematical properties of indicators for biodiversity change. Ecological Indicators, 14: 202-208.

Wang, X., HaO, Z., Ye, J., Zhang, J., Li, B., YaO, X., 2008. Spatial pattern of diversity in an old-growth temperate forest in Northeastern China. Acta Oecologica, 33: 345-354

Washington, H.G., 1984. Diversity, biotic and similarity indices: a review with special relevance to aquatic ecosystems. Water Research, 18: 653-694.

Received October 19, 2018 Accepted March 15, 2019 